\title{
A Journey to Understand Enjoyment in Academic Writing
}

\author{
Kristin K. Janke, PhD ${ }^{1}$; Eliza Dy-Boarman, PharmD²; Bethany Von Hoff, PharmD ${ }^{1}$ \\ ${ }^{1}$ University of Minnesota College of Pharmacy; ${ }^{2}$ Drake University College of Pharmacy \& Health Sciences
}

\begin{abstract}
To assist academic writers in finding enjoyment in writing, this paper draws a distinction between enjoying the process of writing and enjoying the nature of writing. Based on an examination of academic writing literature, analysis of personal experiences, and a review of the positive psychology literature, conditions that support writing enjoyment are posited. Readers are invited to examine their personal experience with writing enjoyment relative to these levers. Concrete actions for authors to improve enjoyment in writing are suggested based on the theories discussed, including actions to support flow, creativity, curiosity, courage, mindset, purpose, and humility.
\end{abstract}

Keywords: academic writing, enjoyment, flow, mindset

en-joy \in-'jöi, en- \

Transitive verb: to take pleasure or satisfaction in ${ }^{1}$

When you think about your academic writing, what emotions do you feel? Is your reaction frustration, guilt and anxiety? Or, is writing a welcomed challenge and rewarding pursuit? Perhaps your experience is somewhere in-between?

Writing can be filled with pressures, tensions, and uncertainties. At times, the pressure to bring projects to fruition may overshadow and stifle the enjoyment that can come from writing. Writing can become something we resist or dread, rather than a positive outlet and a benefit to our academic lives. If we stripped away some of the constraints and frustrations, such as the need to find time to write, the need to meet deadlines, the need to write for promotion or the need to write in a certain way, writing might be better. If we didn't have to work with unresponsive co-authors, unreasonable reviewers, and demanding editors, the milieu for writing might be different. But, many of these changes would rely on changing others, or external forces. What if there were factors within our control that could make writing more enjoyable? Is there another set of conditions that could move us to the positive side of the enjoyment continuum?

We posit that it is possible to find enjoyment in writing. As an academic writing community, we need to explore enjoyment in writing, attempting to understand its elements. In addition, as individual authors, we need to be attentive to variables that might boost or amplify enjoyment. To these ends, the objectives of this commentary are to: 1 ) outline conditions that may contribute to writing enjoyment and 2) provide suggestions for enhancing writing enjoyment.

Corresponding Author: Kristin Janke, University of Minnesota College of Pharmacy, Tel: 612-626-4648 Email: janke006@umn.edu
To prepare this commentary, two of our authors (EDB, KKJ) read Air \& Light \& Time \& Space: How Successful Academics Write by Helen Sword and met on two occasions to discuss its relevance to academic pharmacy. ${ }^{2}$ Simultaneously, a third author (BVH) surveyed the journal literature on academic writing, looking for insights into enjoyment and writing practices. After meeting as a full team, we each wrote our own statement of "Why I enjoy writing" (Table 1). We used these statements and our review of the literature to begin to identify variables that might be related to writing enjoyment, exploring the positive psychology literature for definitions and explanations. We debated these concepts as a group, relating them to our own experiences as authors, meeting regularly for four months as we wrote and developed the ideas presented here.

\section{Writing Enjoyment as a Pursuit}

Somewhat understandably, there is disagreement on the "enjoyability" of writing. In Paul Silvia's How to Write a Lot, he states that while elements of research (e.g. study design, data collection, data analysis) are enjoyable to most academics, "writing is frustrating, complicated, and un-fun." ${ }^{3}$ After a session of slogging through endless word choices, writing and rewriting in an attempt for precision, clarity and concision, many of us would agree. However, Sword's conversations with successful writers suggest that enjoyment is possible. She states that successful writers "write not just because they have to but because they want to" and that much of their productivity comes from the joy that they find in writing. ${ }^{2}$

Joy? In writing? Certainly, there can be reward in laying down elegant, insightful prose that builds into a consequential and significant addition to the field. But joy? Perhaps an appropriate goal might be a smidgen of enjoyment. To orient ourselves more fully to this concept, we turned to Webster's dictionary where "enjoy" is defined as a transitive verb meaning: to take pleasure or satisfaction in. With this, we revisited our statements about enjoyment (Table 1 ). There were certainly sentiments of "taking satisfaction in" writing, 
but the responses seemed to focus on the benefits of writing, like bringing closure to a project and fostering personal development. The focus was more on writing's role and its value to us personally and in our careers. Perhaps "why do I enjoy writing?" was not the appropriate question to help us find enjoyment.

We began to evaluate instances of writing for insight into "taking satisfaction in" writing. It was evident that the where, when, and how of the writing process influenced our enjoyment. For instance, we discussed writing at sunrise with a cup of tea versus writing in the evenings after a nutritious meal and a bit of relaxation. Some preferred writing in the buzz and energy of a coffee shop, while others appreciated quiet and views of nature. We came to realize that the where, when, and how represent the circumstances around the writing. The process of writing is certainly worthy of attention and efforts to optimize. However, the nature of the writing work is equally worthy of observation and interpretation. What are the conditions under which enjoyment thrives? When enjoyment of the act of writing varies, what causes the variance?

We continued to probe our experiences and began examining the positive psychology literature. We discovered that flow theory can provide insights. Flow has been defined as a subjective state of being where the person is absorbed in an activity to the point of forgetting time, fatigue or anything else but that activity. ${ }^{4}$ The conditions for flow include: 1) a perceived challenge or opportunity for action that stretches but does not overmatch existing skills, 2) clear, proximal goals, and 3) immediate feedback about the progress being made. ${ }^{4,5}$ Entering flow requires a delicate balance between perceived challenge and perceived skill. ${ }^{5}$ For example, asking a resident to write a book chapter might fall outside of their perceived level of skill. However, asking them to collaborate with a seasoned author may provide enough of a stretch that the resident is growing, learning, and building writing skills with a reasonable chance of success.

Adjusting the writing challenge is one action that authors can take that may assist in writing satisfaction and enjoyment. Too much challenge may result in frustration or anxiety, but too little challenge may result in a lack of energy or boredom. We could each identify instances where too much or too little challenge was evident. Conceivably, a mismatch between the perceived challenge and perceived skills may affect persistence or determination, which have been identified as important behavioral habits in successful academic writing. ${ }^{2}$ As you think about your most recent writing project, consider the ways it has stretched you. If it hasn't, how could it be molded to do so?

\section{Levers to Influence Writing Enjoyment}

As we further examined our own enjoyable writing experiences, a number of additional conditions were often present. Theory argues, and our personal experience attests, that these conditions can often be influenced or even "activated" at the author's discretion. As such, they function as levers, engaging us and focusing our writing efforts. Table 2 aligns academic writing habits with questions to help authors probe their abilities in that habit area, actions that could be taken to enhance that habit area, and evidentiary support for these actions.

For example, authors might experiment with creativity, which involves generating ideas that are original (i.e. novel, surprising, unexpected) and adaptive. ${ }^{6}$ Creativity can be expressed individually and can also occur in a group, where the assumption is that more can be achieved together than working independently. ${ }^{6}$ In the writing of this commentary, the generation of Table 2 required creativity in merging various theories with a writing habits model to generate a new understanding of the conditions involved in creating satisfaction and enjoyment. The creation of this table was a challenge within the reach of the authorship team, and accepting the creative challenge was invigorating.

Tapping into our curiosity may also aid enjoyment. Curiosity is a motivational state that is focused on approach. ${ }^{7}$ Curious people explore, ask questions and immerse themselves in the interesting. Curiosity's immediate function is to learn. The longer term function is to build knowledge and competence. ${ }^{7}$ Applying these concepts to writing, authors can cultivate curiosity about the subject of their writing, the craft of writing (e.g. "How can I present this information in a different way?") and our own writing processes ("How/When/Where should I write this piece?"). Although we are all pressured by time and the need for productivity, allowing yourself to be curious may re-energize and re-invigorate you, leading to enjoyment.

Demonstrating creativity and curiosity in writing may require courage. At times, we may need to take action despite internal struggles or even external (e.g. political) forces. We may choose to exhibit bravery related to the topics we write on, the style we use, the tone we take, the arguments we make, the audiences we write for, the intellectual traditions we draw from, the visual elements incorporated in our work, or even the places we publish. In addition to bravery, courage has been said to involve persistence, integrity and vigor. Given differences in abilities and situations, the same brave or courageous act for one person may be cowardice for another. ${ }^{8}$ As our capacities related to writing, experience and stature within the academy mature, we might ask ourselves, "To what degree am I willfully, intentionally, and deliberately taking risks related to my writing that leads to a worthy end?" 
Maybe we don't make leaps requiring courage because we are afraid of critical peer review, questioning our intelligence and abilities as a writer and scholar. If we adjust our mindset and re-frame the way we view feedback, we may find more enjoyment in writing. Individuals with growth mindsets believe abilities are malleable and can be increased with effort and learning. Additionally, someone with a growth mindset tends to view challenges or setbacks, such as a rejected paper, as an opportunity to learn. ${ }^{9,10}$ Allowing ourselves to face challenges readily, with the knowledge that we will work hard and improve, may lead to new energy for writing. A fixed mindset can get in the way of our development as writers. Individuals with fixed mindsets tend to worry about proving their abilities. ${ }^{9,10}$ With a fixed mindset, a writer may feel successful because they have mastered a method of writing that has resulted in many published papers. Externally, this looks like confirmation of an ability. Internally, this author may be avoiding challenges, which may stifle dialogue and advancements in research, as well as decrease enjoyment in writing.

But what if we simply can't marshal the energy to push our writing through to completion? Ideally, we are highly driven and engaged in our work. When we're not, it may be useful to probe the writing's connections to our most important strivings. Meaning-in-life researchers argue that purpose, defined as highly motivating, long-term goals about which people are passionate and highly committed, is central and that people will devote significant resources to the pursuit of their purposes. ${ }^{11}$ Is this piece of writing well-aligned with a major aim in my academic life? Is it helping to enact my values? Is it showing what I stand for? Is it connecting me with important conversations within my academic community? If not, can I mold the writing to synergize better with my aims and values? Can it be shaped to connect better with and advance what is important to me? Rather than writing just to satisfy a "publish or perish" mentality, perhaps we need to take a step back to approach our writing with intentionality and attention to purpose.

In addition, an attitude of humility is likely in order. By approaching our writing with humility, we can remain open and receptive to new ideas, advice, and alternative approaches to a project. Our humility can keep us striving and growing. Contrary to dictionary definitions of humility as entailing low self-regard, humility is characterized by experts as involving an accurate assessment of one's capability and the ability to acknowledge gaps in knowledge and limitations. ${ }^{12}$ As we mature as writers, it may be helpful to consider: What is the potential value of ideas and approaches that are decidedly different than mine? What are my weaknesses in this area of inquiry? How might others contribute in pursuit of a stronger, more compelling or convincing publication?

\section{Closing Thoughts}

In order to increase enjoyment in writing, authors may choose to influence a number of conditions related to the nature of writing. We can work to: elevate the level of writing challenge, experiment with creativity, explore and cultivate curiosity, exhibit courage intentionally, approach writing with a growth mindset, and examine and reposition our writing to align with our professional purposes. We were pleased to see so many different levers to increase writing enjoyment. In addition, we recognized that we had already experienced them to some degree, although we may not have been highly aware of their presence or absence.

One additional condition arose time and time again in our discussions and also in the literature: the opportunity for growth and mastery. We shouldn't underestimate the motivational value that can come from the prospect of getting good at writing. Our motivation for improvement might be facilitated by reconceptualizing the role. Helen Sword refers to writers as craftsman stating that they are "makers and shapers of language, in much the same way that weavers are makers and shapers of textiles." ${ }^{2}$ As artisans, we take pride in the work, hone the tools of our trade, and consistently work to refine our craft. Indeed, there is reward, satisfaction and enjoyment in mastery. Therefore, looking after our professional development in writing is wise.

\section{Conclusion}

Our journey to better understand writing enjoyment has lead us to examine enjoyment that may emanate from the value of writing, the process of writing, or the nature of the writing itself. Table 3 provides prompts to consider, should you be interested in exploring enjoyment from these perspectives, as well.

As academic writers, writing productivity is often in the forefront of our minds. However, enjoyment is a worthy pursuit. In conducting her research and writing her book, Sword came to realize that, for her, "productivity is pleasure." She states, "the road to productivity will be a long and tedious one unless you can find meaningful ways to pave it with pleasure." 2 So, how will you pave your academic writing road with pleasure?

Acknowledgements: None

Financial Disclosures: None

Other Disclosures: Kristin Janke is Editor for the education section of Innovations in Pharmacy. 


\section{References}

1. Available at: https://www.merriamwebster.com/dictionary/enjoy. Accessed October 1 , 2018.

2. Sword, Helen. Air \& Light \& Time \& Space: How Successful Academics Write. Cambridge, MA: Harvard University Press; 2017.

3. Silvia, Paul J. How to Write a Lot. Washington, DC: American Psychological Association; 2007.

4. Csikszentmihalyi M, Abuhamdeh S, Nakamura J. Flow. In: Flow and the Foundations of Positive Psychology: The Collected Works of Mihaly Csikszentmihalyi. New York, NY: Springer; 2014:227238.

5. Nakamura J, Csikszentmihalyi M. Flow Theory and Research. In: Lopez SJ, Snyder CR, eds. Oxford Handbook of Positive Psychology. 2nd ed. New York, NY: Oxford University Press; 2009:195-206.

6. Simonton DK. Creativity. In: Lopez SJ, Snyder CR, eds. Oxford Handbook of Positive Psychology. 2nd ed. New York, NY: Oxford University Press; 2009:261269.

7. Kashdan TB, Silvia PJ. Curiosity and Interest: The Benefits of Thriving on Novelty and Challenge. In: Lopez SJ, Snyder CR, eds. Oxford Handbook of Positive Psychology. 2nd ed. New York, NY: Oxford University Press; 2009:367-374.

8. Pury CLS, Lopez SJ. Courage. In: Lopez SJ, Snyder CR, eds. Oxford Handbook of Positive Psychology. 2nd ed. New York, NY: Oxford University Press; 2009:375-382.

9. Dweck CS. Mindset: The New Psychology of Success. How We Can Learn to Fulfill Our Potential. New York, NY: Ballentine Books; 2006.

10. Dweck CS. Self Theories: Their Role in Motivation, Personality, and Development. Philadelphia, PA: Psychology Press; 2000.

11. Steeger, MF. Meaning in Life. In: Lopez SJ, Snyder CR, eds. Oxford Handbook of Positive Psychology. 2nd ed. New York, NY: Oxford University Press; 2009:679-688.

12. Tangney JP. Humility. In: Lopez SJ, Snyder CR, eds. Oxford Handbook of Positive Psychology. 2nd ed. New York, NY: Oxford University Press; 2009:483490.

\section{Authors' Bios}

Kristin Janke is professor and director of the Wulling Center for Innovation \& Scholarship in Pharmacy Education. Her interest in writing has been sparked and nurtured by roles on three editorial boards. Now, as an editor, she enjoys working with authors to help them frame their ideas and convey their experiences in advancing education. For the past five years, she has worked with pharmacy education journals to expand the available options for publishing by creating a continuum of article types that allows authors to share a breadth of scholarly experiences. In addition, she currently coordinates the \#RxWritingChallenge, which unites pharmacy authors twice per year to focus on writing for a 14-day challenge.

Eliza Dy-Boarman is an assistant professor of pharmacy practice at Drake University and an internal medicine clinical pharmacy specialist at UnityPoint Health - Des Moines lowa Lutheran Hospital. She coordinates the second professional year introductory pharmacy practice experiences, precepts an acute care advanced pharmacy practice experience, and teaches in a laboratory-based skills and applications course series. Her research interests focus on the scholarship of teaching and learning. She is passionate about advancing scholarly teaching through the scholarship of teaching and learning, informing the greater academy of evidence that will inform their teaching, scholarship, and service, and collaborating with colleagues to produce the highest quality writing.

Bethany Von Hoff is a graduate student at the University of Minnesota College of Pharmacy in the Social and Administrative Pharmacy program. She is also a practicing pharmacist at the Mayo Clinic. Her teaching and research interests are focused on understanding and helping student pharmacists develop professionally. Transitioning from a PharmD program to a PhD program changed the way she thinks about writing. Especially in educational research, she had to shift from the randomized controlled trial being the gold standard to embracing qualitative and mixed method studies exploring smaller cohorts, student experiences, and narratives. Making this transition after many years of traditional "scientific writing" has changed the way she views reading and writing of academic literature. 
Table 1. Initial Personal Statements on "Why I enjoy writing..."

Writing crystalizes and celebrates the inquiry... Kristin Janke

After (oftentimes) years of work, writing helps to bring closure to a project, allowing some finality. We can say, "Hey World, we did this!" When done well, writing celebrates the work. It allows us to describe the work's purpose and spell out its importance. In addition, writing situates the work and prepares others to add to it. As a form of documentation, writing adds to the accumulated history, helping to ensure that the work matters through its permanence. As a form of communication, it helps me to feel that I'm "paying it forward," sharing hard won insights that can help someone else jump start their efforts. Writing also builds collegiality. As a team, a sense of pride develops as we talk through and capture our thoughts. As we attempt to tell our story, we inevitably discover something new about our work and we are re-charged and focused to take on the next step in inquiry.

\section{I develop, and the work develops through writing... Eliza Dy-Boarman}

While my scholarly activities have developed through a gradual and deliberate process, writing has always been a natural, personally-fulfilling process. I most enjoy writing when I have an idea or experience that I am eager to share with others and am able to envision how my writing may impact those readers. When beginning the writing process, I get excited about finding the right words to describe my thoughts. In fact, I enjoy the challenge of incorporating style and creativity into works that are heavily dominated by scientific narratives. Ultimately, I most enjoy seeing my work come together as a complete document and reading the fully-developed and edited end-product. I associate my most successful writing experiences with personal development, and I am most proud of those pieces that have truly challenged me and have fully transformed from the first to final draft.

\section{Writing makes the research come alive.... Bethany Von Hoff}

I enjoy writing the most when the words can't help but come alive on the page. It's as if all of the background knowledge, my experiences, and the findings converge at once. I can get lost in the words and the story l'm trying to tell. When this happens, writing feels like a natural extension of my thoughts. When writing is done, being able to share my writing with others makes me feel like my research has come alive. It may be the thing I most appreciate and value about writing. It's one thing to say “I'm interested in this topic" or "I'm doing research in this area," but to be able to provide tangible evidence of all of the hours spent reading, writing, and editing provides a sense of accomplishment that's hard to beat. 
Table 2. Aligning Writing Habits with Specific Actions for Enhancing Enjoyment

\begin{tabular}{|c|c|c|c|}
\hline $\begin{array}{l}\text { Habit Area and } \\
\text { Key Habits }\end{array}$ & $\begin{array}{l}\text { Reflective Questions } \\
\text { to Explore the Habits }\end{array}$ & Possible Author Actions & Support from Theory \\
\hline $\begin{array}{l}\text { Behavioral } \\
\text { persistence, } \\
\text { determination, } \\
\text { passion, } \\
\text { pragmatism, } \\
\text { "grit" }\end{array}$ & $\begin{array}{l}\text { How am I carving out } \\
\text { time for my writing? } \\
\text { What settings are } \\
\text { most conducive for } \\
\text { my writing? } \\
\text { What writing } \\
\text { processes encourage } \\
\text { my productivity? }\end{array}$ & $\begin{array}{l}\text { Control the level or type of writing challenge } \\
\text { to stretch but not over-extend skills } \\
\text { Set proximal goals that provide direction and } \\
\text { purpose to the work } \\
\text { Obtain timely feedback on progress } \\
\text { Explore passion related to writing and } \\
\text { recognize the motivation that can come from } \\
\text { meaning/purpose } \\
\text { Be intentional in pursuing writing that aligns } \\
\text { with purpose }\end{array}$ & $\begin{array}{l}\text { Meaning/purpose } \\
\text { (passion) }\end{array}$ \\
\hline $\begin{array}{l}\text { Artisanal } \\
\text { creativity, craft, } \\
\text { artistry, } \\
\text { patience, } \\
\text { practice, } \\
\text { perfectionism } \\
\text { [but not too } \\
\text { much!], a } \\
\text { passion for } \\
\text { lifelong learning }\end{array}$ & $\begin{array}{l}\text { What is it that I enjoy } \\
\text { about using language? } \\
\text { What are the current } \\
\text { gaps in my writing } \\
\text { abilities? }\end{array}$ & $\begin{array}{l}\text { Keep a growth mindset to assist you with } \\
\text { continued writing skill development } \\
\text { Challenge yourself to generate ideas that are } \\
\text { original and adaptive } \\
\text { Allow yourself to be curious by asking } \\
\text { questions about the subject of the writing, the } \\
\text { craft of writing and the writing process }\end{array}$ & $\begin{array}{l}\text { Mindset } \\
\text { Creativity Theory } \\
\text { Curiosity Theory }\end{array}$ \\
\hline $\begin{array}{l}\text { Social } \\
\text { collegiality, } \\
\text { collaboration, } \\
\text { generosity, } \\
\text { openness to } \\
\text { both criticism } \\
\text { and praise }\end{array}$ & $\begin{array}{l}\text { How will my work } \\
\text { impact my readers? } \\
\text { How can I write with } \\
\text { and among others? }\end{array}$ & $\begin{array}{l}\text { Seek an accurate assessment of your writing } \\
\text { abilities } \\
\text { Acknowledge gaps in knowledge and } \\
\text { limitations } \\
\text { Remain open to new ideas, contradictory } \\
\text { information and advice } \\
\text { Appreciate the value of diverse approaches } \\
\text { and the multiple ways that others can } \\
\text { contribute }\end{array}$ & Humility Theory \\
\hline $\begin{array}{l}\text { Emotional } \\
\text { positivity, } \\
\text { enjoyment, } \\
\text { satisfaction, } \\
\text { risk taking, } \\
\text { resilience, luck }\end{array}$ & $\begin{array}{l}\text { What previous } \\
\text { circumstances led to } \\
\text { positive writing } \\
\text { experiences? } \\
\text { How can I turn } \\
\text { frustration into } \\
\text { motivation? }\end{array}$ & $\begin{array}{l}\text { Intentionally and deliberately take risks } \\
\text { related to writing in order to achieve a worthy } \\
\text { end. } \\
\text { Ask other authors about their courageous } \\
\text { actions in writing to inspire your own actions. }\end{array}$ & Courage Theory \\
\hline
\end{tabular}


Table 3. Prompts for Exploring Enjoyment in Writing

\begin{tabular}{ll}
\hline \multicolumn{1}{c}{ Facet } & \\
\hline The Value of Writing & $\begin{array}{l}\text { Why I enjoy writing... } \\
\text { I value and/or appreciate my work as a writer because... } \\
\text { The personal benefits to writing include... }\end{array}$ \\
& $\begin{array}{l}\text { I enjoy writing the most when.... } \\
\text { The Process of Writing }\end{array}$ \\
$\begin{array}{l}\text { The Nature or Conditions of } \\
\text { Writing }\end{array}$ & $\begin{array}{l}\text { What examples do I have of flow, creativity, curiosity, courage, mindset, purpose, and/or } \\
\text { humility? } \\
\text { How can I modify my writing work to tap into one of these conditions more strongly? }\end{array}$ \\
\hline
\end{tabular}

